Volume 2 Nomor 2, Desember 2019

\title{
TANGGUNG JAWAB PENGANGKUT TERHADAP PENUMPANG YANG TIDAK TERDAFTAR DALAM MANIFES (STUDI KASUS JATUHNYA PESAWAT LION AIR JT 610 DI KARA WANG)
}

\author{
Abimanyu Faiz Prajogo \\ (Mahasiswa Program S1 Fakultas Hukum Universitas Tarumanagara) \\ abmnyufp@gmail.com \\ Prof. Dr. H.K. Martono, S.H., L.L.M. \\ (Corresponding Author) \\ (Dosen Fakultas Hukum Universitas Tarumanagara, Meraih Sarjana Hukum \\ pada Fakultas Hukum Universitas Universitas Indonesia) \\ (E-mail: martono@fh.untar.ac.id)
}

\begin{abstract}
Lion Air with fligh code JT-610 route Jakarta to Pangkal Pinang on October 29 ${ }^{\text {th }}$, 2028 which crashed in Karawang Waters carrying 178 passengers, one child passenger, 2 babies, and 7 cabin crew. On the plane there are passengers who are not on the ticket or not registered. Issues issued are how the responsibility of the carrier in an aircraft accident that is not listed in the passenger manifest. The research method used in this thesis research is normative legal research. The results of the research prove that passengers who are not in the manifest may receive compensation, but only compensate for voluntary purchases. It may be possible to request ex gratia or voluntarily to buy a passenger ticket that cannot be ordered in the passenger manifest. However, based on information compiled from PT Jasa Raharja, checking the heirs or families of victims of the crash of the Lion Air JT 610 aircraft which were not equipped in the manifest of the aircraft could still receive compensation. In cases that substitute for consumer rights, caution is needed in analyzing who should be held responsible and asking for the responsibilities required for the parties concerned.
\end{abstract}

Keywords: Responsibility of Carrier, Airplane, Lion Air

\section{PENDAHULUAN}

\section{A. Latar Belakang}

Transportasi ialah hal yang cukup penting untuk membantu kehidupan masyarakat dalam mencapai suatu tujuan yang akan didatangi. Salah satu transpotasi yang cukup banyak diminati di era globalisasi ini adalah transportasi udara. Menggunakan layanan pesawat terbang sudah bukan lagi menjadi hal yang mewah melainkan suatu kebutuhan masyarakat yang harus terpenuhi. Semakin meningkatnya jumlah kalangan masyarakat menengah ke atas di Indonesia mengakibatkan kebutuhan berpergian 
menggunakan pesawat semakin meningkat. Baik berpergian untuk masalah pekerjaan, mengunjungi keluarga maupun berlibur. Dengan menggunakan transportasi udara, dapat memberikan kecepatan dan kenyamanan kepada para penggunanya terutama bagi mereka yang memiliki keterbatasan waktu. Hal tersebut memberikan dampak terhadap pertumbuhan transportasi penerbangan.

Transportasi di era ini mengalami peningkatan yang cukup signifikan, ini dapat di nilai dari meningkatnya perusahaan atau maskapai penerbangan yang memberikan layanan jasa penerbangan ke berbagai rute destinasi baik rute domestik ataupun internasional. Sarana transportasi udara adalah transportasi yang sangat efektif, efisien, cepat dan nyaman. Peranan dari transportasi udara khususnya penerbangan komersial sangat penting dalam hal perkembangan ekonomi dan sosial yang dinilai dari meningkatnya jumlah pemintaan jasa layanan penerbangan yang diukur dari angka penumpang setiap waktunya.

Saat ini maskapai penerbangan menjadi driver dalam dunia transportasi. Industri penerbangan di Indonesia masuk dalam katagori pertumbuhan tercepat di Asia. Ada beberapa faktor pendukung konsumen memilih jasa transportasi udara, antara lain untuk kepentingan negara, kepentingan bisnis, kepentingan pariwisata, dan bermacam urusan yang lain. Industri-industri penerbangan di Indonesia maupun asing berkompetisi untuk menarik daya minat penumpang sebanyak mungkin dengan memberikan promosi harga yang lebih rendah atau memberikan bermacam bonus. Terkadang dengan harga tiket yang murah, seringkali perusahaan penerbangan mengesampingkan kualitas pada layanan mereka.

Pesawat udara menjadi sarana penghubung yang cepat dan efektif, sehingga pesawat udara menjadi pilihan yang pertama dalam hal berpergian jarak jauh. Pesawat udara mempunyai keistimewaan tersendiri diantaranya sanggup mencapai destinasi tujuan batas suatu negara dengan 
Volume 2 Nomor 2, Desember 2019

durasi waktu yang cukup cepat dan memanfaatkan teknologi canggih. ${ }^{1}$ Transportasi menggunakan pesawat udara adalah sarana transportasi berupa jasa yang disediakan oleh perusahaan penerbangan yang kegiatan utamanya adalah jasa pengantaran orang atau barang dari satu tempat ke tempat lainnya. ${ }^{2}$ Serta di dukung oleh sarana prasarana yaitu bandar udara. Undang-Undang Nomor 1 Tahun 2009 tentang Penerbangan cukup menjanjikan terhadap pertumbuhan pengangkutan udara di Indonesia. Undang-Undang tersebut secara komprehensif mengatur kedaulatan wilayah udara Indonesia, dan berbagai aturan baru guna menjamin keselamatan penerbangan di Indonesia. ${ }^{3}$

Salah satu macam trasnportasi yang sangat diperlukan oleh manusia dalam pemenuhan kebutuhannya ketika berpergian jarak jauh yakni transportasi udara. Transportasi udara menjadi alat transportasi yang cukup mutakhir dan tercepat dengan cakupan yang luas karena memiliki beberapa kelebihan, yakni diantaranya:

1. Sisi kecepatan

2. Transportasi udara bisa mengantarkan penumpang ke daerah pegunungan dan berjurang-jurang.

3. Bagi angkutan yang jaraknya cukup jauh, akan lebih efisien dalam hal mempersingkat waktu di dalam perjalanan.

4. Tersedianya jadwal yang teratur dan frekuensi penerbangan. ${ }^{4}$

Angkutan udara yakni kegiatan mengangkut penumpang, pos dan kargo menggunakan pesawat udara, dari satu perjalanan atau lebih, dari satu bandar udara menuju bandar udara yang lain. Terjadi peningkatan

1) Abidin A. Kurnia Ecla Julianto, Tanggung Jawab Maskapai Penerbangan Terhadap Penumpang dan Bagasi Kabin dalam Kecelakaan Pengangkutan Udara di Indonesia, (Skripsi, Universitas Muhammadiyah Yogyakarta, 2015). hal 1.

2) Fadia Fitriyanti dan Sentot Yulianugroho, Hukum Perniagaan Internasional, (Yogyakarta: Lab Hukum Universitas Muhammadiyah Yogyakarta, 2007), hal 71.

3) H.K Martono \& Agus Pramono, Hukum Udara Perdata Nasional dan Internasional, (Jakarta: Raja Grafindo Persada, 2013), hal . 188.

4) Rustian Kamaluddin, Ekonomi Transportasi: Karekteristik, Teori dan Kebijakan, (Jakarta:Ghalia Indonesia,2003), hal. 75. 
yang cukup signifikan pada penerbangan niaga di Indonesia dengan mengukur dari besarnya potensi jumlah penumpang dan maraknya maskapai penerbangan yang ada, baik domestik ataupun internasional yang memberikan jasa layanan penerbangan ke berbagai destinasi tujuan. Perusahaan maskapai penerbangan niaga di Indonesia antara lain Garuda Indonesia, Citilink, Sriwijaya Air, Lion Air, dan lain-lain.

Salah satu alasan pendukung konsumen memakai jasa layanan transportasi udara adalah untuk memberikan kemudahan dalam berpergian jarak jauh dan tidak menghabiskan waktu lama selama di perjalanan. Jika ditinjau dari sisi penyelenggaraan penerbangan, terdapat 2 pola kegiatan penerbangan yakni penerbangan komersil dan penerbangan bukan komersil. Penerbangan komersil atau niaga adalah bentuk transportasi udara yang membebankan biaya penerbangan kepada penumpangnya. Penerbangan komersil dibedakan menjadi dua macam, yakni penerbangan niaga berjadwal dan penerbangan niaga tidak berjadwal.

Pertumbuhan jumlah perusahaan penerbangan didunia, dilain segi memberikan keuntungan untuk para pemakai jasa transportasi udara karena memiliki berbagai macam alternatif pilihan maskapai penerbangan yang bisa mereka pilih. Sudah banyak maskapai penerbangan yang ada saat ini menggunakan sistem LCC (low cost carrier) yaitu dana operasional yang minim dimana maskapai penerbangan menggunakan dana operasional yang digunakan dan melakukan efisiensi. Perusahaanperusahaan penerbangan tersebut telah membangun situasi perdagangan yang cukup bersaing antar perusahaan maskapai penerbangan lainnya. Mereka berkompetisi agar menarik minat penumpang sebanyak mungkin dengan mempromosikan harga tiket yang lebih rendah atau memberikan berbagai tambahan ekstra yang diincar konsumen dengan antusias. Dari segi lain, dengan tarif tiket yang rendah tersebut seringkali mengurangi taraf kualitas dalan pelayanan, justru yang lebih mencemaskan lagi yaitu akan mengakibatkan menurunnya kualitas pemeliharaan dan perawatan 
terhadap pesawat sehingga berbahaya untuk keselamatan dan berdampak kurang baik pada keamanan, kenyamanan dan perlindungan penumpang.

Transportasi menggunakan pesawat yang bertujuan untuk mengangkut berupa barang, penumpang, kargo yang melakukan perjalanan dari satu tempat menuju ke tempat lainnya adalah pengertian dari angkutan udara. Salah satu yang berkembang dari moda transportasi udara adalah penerbangan niaga. Penerbangan niaga mengalami kenaikan yang sangat tinggi. Ini terjadi karena semakin meningkatnya kuantitas oenumoang dan perusahaan penerbangan baik dalam negeri maupun luar negeri. Dilihat dengan acuan perusahan-perusahan membuka rute penerbangan yang banyak baik domestic maupun internasional.

Terdapat beberapa alasan konsumen memilih jasa transportasi udara, antara lain untuk kepentingan bisnis, kepentingan pariwisata, dan berbagai urusan lainnya. Jika dilihat dari segi penyelenggaran penerbangan, maka dapat disebutkan dua jenis bentuk kegiatan penerbangan, yaitu penerbangan yang menguntungkan atau bisa disebut juga penerbangan komesil dan juga penerbangan yang tidak menguntungkan disebut juga dengan penerbangan non komersil contohnya adalah seperti penerbangan untuk kepentingan militer. Penerbangan komersil atau niaga merupakan bentuk transportasi udara yang mengenakan biaya bagi penggunanya. Bentuk penerbangan Niaga dibedakan menjadi dua dari segi aspek penyelenggaraan penerbangan, yaitu penerbangan niaga berjadwal dan penerbangan niaga tidak berjadwal.

Maraknya perusahaan penerbangan di satu sisi memudahkan bagi para pengguna jasa transportasisi udara karena makin banyak pilihan. Kebanyakan perusahaan penerbangan menerapkan sisten low cost carrier karena dengan menerapkan system itu maskapai dapat menekan baiaya operasional mereka. Perusahaan-perusahaan penerbangan tersebut telah melahirkan iklim yang kompetitif antara satu maskapai penerbangan dengan maskapai penerbangan lainnya. Maskapai-maskapai tersebut 
Abimanyu Faiz Prajogo \& H. K. Martono TANGGUNG JAWAB PENGANGKUT TERHADAP PENUMPANG YANG TIDAK TERDAFTAR DALAM MANIFES (STUDI KASUS JATUHNYA PESAWAT LION AIR JT 610 DI KARAWANG)

Volume 2 Nomor 2, Desember 2019

E-ISSN : 2655-7347

bersaing untuk menarik penumpang sebanyak-banyaknya dengan menawarkan tarif yang lebih murah atau menawarkan berbagai bonus. Di satu sisi, diterapkannya tariff yang terjangkau akan menimbulkan kurangnya kualitas pelayanan, bahkan lebih parahnya lagi pemeliharaan dan perawatan pesawat menjadi terabaikan. Karena menurunnya kualitas perawatan dan pemeliharaan sangat beresiko kepada keselamatan dan keamanan penerbangan tersebut baik bagi penumpang maupun perusahaan yang dapat menimbulkan kerugian yang besar. Akibat seringnya terjadi kecelakaan akan menimbulkan kekhawatiran bagi konsumen. Hal-hal yang menjadi keresahan penumpang yang dapat menyebabkan keresahan seperti halnya keterlambatan jadwal penerbangan, kehilangan dan kerusakan barang yang diangkut dengan pesawat terbang dan sebagainya. ${ }^{5}$ Terdapat dua pihak dalam kegiatan penerbangan Niaga, yaitu pengangkut dalam hal ini adalah perusahaan atau maskapai penerbangan dan pihak pengguna jasa atau konsumen. Para pihak tersebut terikat oleh suatu perjanjian, yaitu perjanjian pengangkutan. Perjanjian dalam angkutan udara bersifaat keperdataan yang dimana terdapat unsur hak dan kewajiban yagn dimana wajib melaksanakan hak dan kewajiban yang harus dipenuhi dan biasa dikenal dengan istilah prestasi. Itu semua tercantum didalm manifestasi.

Terdapat aspek yang merupakan unsur-unsur dalam perlindungan konsumen khususnya system perlindungan hokum bagi konsumen jasa angkatan udara. Aspek-aspek tersebut adalah keselamatan, keamanan, kenyamanan, pelayanan, pentarifan, dan perjanjian angkutan udara. Semua system perlindungan hukum dimulai sejak pembuatan pesawat udara sampai tempat tujuan ataupun jika mengalami kecelakaan, sampai ia dan ahli warisnya mendapatkan ganti rugi. Pesawat Lion Air dengan kode penerbangan JT-610 rute Jakarta - Pangkalpinang mengalami kecelakan

5) Wagiman, Refleksi dan Implemantasi Hukum Udara: Studi Kasus Pesawat Adam Air, Jurnal Hukum Bisnis Vol. 25, 2006, hal 13. 
pada tanggal 29 Agustus 2019. Pesawat tersebut jatuh di perairan karawang yang membawa penumpang 178 penumpang dewasa, satu penumpang anak-anak, 2 bayi, serta 7 awak kabin. Di dalam pesawat tersebut ada penumpang yang namanya tidak ada dalam tiket atau tidak terdaftar dalam manifest penumpang. PT SKY Pasific Indonesia menugaskan Krisma wijaya, Darwin Harianto dan Rohmanir Pandi Sagala ke Pangkalpinang. Mereka Bertiga tugas ke Pangkal Pinang menggunakan Pesawat Lion Air yang sudah di pesan. Mereka Bertiga bertugas ke Pangkal Pinang menggunakan Pesawat Lion Air yang sudah di pesan. Tiga hari sebelum berangkatnya Krisma Wijaya mengundurkan diri untuk tidak tugas ke Pangkal Pinang. Lalu digantikan oleh Yustian. Pada saat mereka pergi, pesawat yang mereka tumpangi jatuh di perairan Karawang dan pada saat pengecekan tidak terdaftar nama Arif Yustian, yang tertera dan terdaftar adalah Krisma Wijaya.

Telah terjadi kecelakaan pesawat Lion Air dengan kode penerbangan JT-610 rute Jakarta menuju Pangkal Pinang pada tanggal 29 Oktober 2018. Pesawat tersebut jatuh di perairan Karawang yang membawa 178 penumpang dewasa, 1 penumpang anak-anak, 2 bayi, dan 7 awak kabin. Di dalam pesawat tersebut ada penumpang yang namanya tidak ada dalam tiket atau tidak terdaftar. PT SKY Pasific Indonesia menugaskan Krisma wijaya, Darwin Harianto dan Rohmanir Pandi Sagala ke Pangkal Pinang. Mereka bertiga ditugaskan ke Pangkal Pinang menggunakan Pesawat Lion Air yang sudah di pesan. Tiga hari sebelum keberangkatan Krisma Wijaya menginfokan bahwa ia tidak bisa pergi tugas ke Pangkal Pinang. Kemudian ketidakhadiran Krisma Wijaya digantikan oleh Arif Yustian. Pada saat mereka di tengah perjalanan menaiki pesawat udara Lion Air JT610 rute Jakarta menuju Pangkal Pinang, pesawat terbang yang mereka tumpangi mengalami kecelakaan dan terjatuh di perairan Karawang. Pada saat pengecekan data manifes para korban kecelakaan pesawat tersebut, 
Abimanyu Faiz Prajogo \& H. K. Martono TANGGUNG JAWAB PENGANGKUT TERHADAP PENUMPANG YANG TIDAK TERDAFTAR DALAM MANIFES (STUDI KASUS JATUHNYA PESAWAT LION AIR JT 610 DI KARAWANG)

Volume 2 Nomor 2, Desember 2019

E-ISSN : 2655-7347

ternyata tidak ada terdaftar nama penumpang atas nama Arif Yustian, yang tertera dan terdaftar melainkan Krisma Wijaya.

Berdasarkan uraian tersebut, maka diangkatlah judul penelitian ini yaitu: "TANGGUNG JAWAB PENGANGKUT TERHADAP PENUMPANG YANG TIDAK TERDAFTAR DALAM MANIFES (STUDI KASUS JATUHNYA PESAWAT LION AIR JT 610 DI KARAWANG)"

\section{B. Rumusan Masalah}

Berdasarkan latar belakang yang telah di uraikan, penulis mengangkat permasalahan yang dirumuskan yakni bagaimana tanggung jawab pengangkut dalam kecelakaan pesawat terbang yang tidak terdaftar dalam manifes penumpang?

\section{Metode Penelitiann}

1. Tipe Penelitian

Tipe yang digunakan dalam penelitian ini adalah metode penelitian hukum normatif. Yang merupakan penelitian hukum untuk menemukan kebenaran koherensi (dipercaya dalam pikiran), yaitu adalah norma hukum dan adakah norma yang berupa perintah atau larangan itu sesuai dengan prinsip hukum, serta apakah tindakan (act) seseorang sesuai dengan norma hukum (bukan hanya sesuai aturan hukum) atau prinsip hukum. ${ }^{10)}$

2. Jenis Data Penelitian

Sumber-sumber penelitian hukum dapat berupa bahan-bahan hukum primer, sekunder, dan bahan non hukum. Bahan-bahan hukum yang akan dipergunakan dalam penelitian ini meliputi:

a. Bahan Hukum Primer

${ }^{10)}$ Peter Mahmud Marzuki, Metode Penelitian Hukum, Cetakan ke-4, (Jakarta: Kencana, 2008), hal. 47. 
Abimanyu Faiz Prajogo \& H. K. Martono TANGGUNG JAWAB PENGANGKUT TERHADAP PENUMPANG YANG TIDAK TERDAFTAR DALAM MANIFES (STUDI KASUS JATUHNYA PESAWAT LION AIR JT 610 DI KARAWANG)

Volume 2 Nomor 2, Desember 2019

E-ISSN : 2655-7347

Bahan hukum primer adalah bahan hukum yang bersifat autoritatif artinya memiliki otoritas. Bahan-bahan hukum primer terdiri dari peraturan perundang-undangan. ${ }^{11)}$ Bahan hukum yang dipakai diantaranya:, Kitab Undang-Undang Hukum Pidana (KUHP), Peraturan Menteri Nomor 77 Tahun 2011 tentang tanggung Jawab Pengangkut Angkutan Udara, Undang-Undang Nomor 1 Tahun 2009 tentang Penerbangan.

b. Bahan Hukum Sekunder

Bahan hukum sekunder adalah bahan hukum yang menunjang bahan-bahan hukum primer. Bahan hukum sekunder yang terutama adalah buku-buku hukum dan jurnal-jurnal hukum. ${ }^{12)}$ Bahan sekunder yang digunakan dalam penelitian ini antara lain artikel ilmiah, buku-buku, laporan-laporan penelitian, jurnal, skripsi, tesis, disertasi dan dokumen yang berasal dari internet.

c. Bahan Non-Hukum

Bahan non-hukum yakni bahan hukum yang mendukung bahan hukum primer dan bahan hukum sekunder dengan memberikan pemahaman dan pengertian atas bahan hukum lainnya. Bahan hukum yang dipergunakan adalah Kamus Lengkap Bahasa Indonesia.

3. Teknik Pengumpulan Data

Teknik pengumpulan bahan hukum melalui studi dokumen atau bahan pustaka yakni pengumpulan bahan hukum tertulis.

4. Teknik Pengolahan Data

Setelah bahan hukum dihimpun, dilakukan pengolahan bahan hukum, yaitu menggodok bahan hukum sedemikian rupa sehingga bahan hukum tersebut tersusun secara runtut dan sistematis kedalam kelaskelas dari indikasi-indikasi yang sama atau yang dianggap sama, 
sehingga mempermudah peneliti dalam melakukan analisis. Penggodokan bahan hukum seperti itu disebut sebagai klasifikasi.

Pada penelitian normatif, pengolahan bahan hukum berwujud kegiatan untuk mengadakan sistematisasi terhadap bahan hukum tertulis dengan cara melakukan seleksi bahan hukum sekunder dilanjut dengan kualifikasi dan menyusun hasil penelitian tersebut secara sistematis dan logis.

5. Teknik Analisis Data

Teknik analisis bahan hukum yang dipergunakan oleh peneliti ialah tekhnik kualitatif dan sifat analisis deskriptif. Pada analisis yang bersifat deskriptif ini peliti membagikan gambaran atau paparan atas subjek dan objek penelitian sebagaimana hasil penelitian yang diperoleh. Penelitian hukum pada dasarnya adalah suatu kegiatan ilmiah yang didasarkan pada metode, sistematika dan pemikiran tertentu, yang bertujuan untuk mempelajari satu atau beberapa gejala hukum tertentu dengan jalan menganalisisnya, serta melakukan pemeriksaan secara mendalam atas fakta hukum tersebut untuk kemudian mengusahakan suatu pemecahan atas permasalahanpermasalahan yang timbul di dalam gejala yang bersangkutan.

cara melakukan telaah tertutup kasus-kasus yang berkaitan dengan isu yang dihadapi yang telah menjadi putusan pengadilan yang telah menjadi putusan pengadilan yang telah mempunyai kekuatan hukum tetap. ${ }^{14)}$

\section{PEMBAHASAN}

Dalam penjelasan Undang-Undang Nomor 15 Tahun 1992 tentang Penerbangan (Undang-Undang Penerbangan) disebutkan bahwa transportasi memiliki peranan penting dalam pembangunan ekonomi bangsa. Hal ini demikian adanya karena transportasi merupakan sarana penghubung antara satu

${ }^{14)}$ Ibid., hal. 134 
Volume 2 Nomor 2, Desember 2019

daerah dengan daerah lainnya. Kesadaran akan pentingnya angkutan udara sebagai salah satu sarana transportasi dimulai semenjak berakhirnya perang Dunia kedua.

Pada dasarnya, penerbangan, sebagai salah satu unsur dari transportasi, harus dikelola secara terpadu sehingga dapat memenuhi unsur keselamatan dan keamanan yang semaksimal mungkin. Undang-undang penerbangan memberikan kewenangan kepada pemerintah untuk membina penerbangan di Indonesia. Salah satu poin penting yang terdapat di dalam undang-undang penerbangan adalah pernyataan mengenai keanggotaan indonesia dalam ICAO. Dalam penjelasan undang-undang penerbangan, dikatakan bahwa indonesia (dalam hal ini adalah pemerintah) memiliki kewajiban untuk menyelaraskan pengaturan sistem penerbangannya dengan ketentuan-ketentuan yang terkandung di dalam konvensi Chicago 1944. Dengan adanya ketentuan ini, terdapat satu kejelasan bahwa pengaturan sistem penerbangan di indonesia diharuskan untuk mengacu pada ketenttuan internasional. Selain itu, penataan terhadap ketentuan ICAO oleh Indonesia merupakan suatu konsekuensi logis dari keikutsertaan Indonesia dalam konvensi Chicago 1944 yang melahirkan ICAO.

Undang-Undang Penerbangan Indonesia terdiri dari 15 Bab dan 76 Pasal. Dari jumlah tersebut, ketentuan yang secara langsung berkaitan dengan keselamatan penerbangan terdapat dalam Bab 7 hingga Bab 9 yang terdiri dari 18 Pasal. Bab 7 berjudul keaman dan keselamatan terbang, Bab 8 berjudul Bandar Udara, dan Bab 9 berjudul pencarian dan pertolongan kecelekaan serta penelitian sebab-sebab kecelakaan pesawat Udara. Kesemua ketentuan yang terkandung dalam ketiga Bab tersebut merupakan ketentuan yang diadopsi dari ketentuan Hukum Udara Internasional. Dapat dikatakan bahwa pengaturan keselamatan dunia penerbangan Indonesia saat ini telah mengacu kepada ketentuan penerbangan Internasional.

Peraturan Pemerintah Nomor 3 Tahun 2001 tentang keamanan dan keselamatan Penerbangan (Peraturan Pemerintah tentang Keamanan dan 
Abimanyu Faiz Prajogo \& H. K. Martono TANGGUNG JAWAB PENGANGKUT TERHADAP PENUMPANG YANG TIDAK TERDAFTAR DALAM MANIFES (STUDI KASUS JATUHNYA PESAWAT LION AIR JT 610 DI KARAWANG)

Volume 2 Nomor 2, Desember 2019 E-ISSN : 2655-7347

Keselamatan Penerbangan) merupakan peraturan yang menjabarkan lebih lanjut ketentuan undang-undang Penerbangan. Terdiri dari 14 Bab dan 104 Pasal, isi peraturan ini menegaskan bahwa keselamatan penerbangan merupakan suatu kondisi yang hanya dapat terwujud dengan penataan terhadap prosedur operasi dan persyaratan teknis terhadap sarana prasana penerbangan. Dikarenakan penekanan terhadap keselamatan penerbangan terpaku pada kata penataan, maka segenap ketentuan dalam peraturan pemerintah tentang Keamanan dan Keselamatan Penerbangan ditujukan kepada pihak operator dan regulator.

Berkenaan dengan penataan itu sendiri, terdapat satu pelajaran berharga yang wajib ditangkap oleh operator dan regulator. Kedua pihak membutuhkan kejujuran dan integritas dalam melaksanakan operasi penerbangan. Apabila pesawat mengalami kerusakan sekecil apa pun yang dapat menggangu keselamatan suatu penerbangan, menjadi bijaksan dan benar bila operator tidak menggunakan pesawat tersebut. Pihak operator juuga dituntut untuk memiliki manajemen yang mengerti bahkan berpengalaman dibidang penerbangan. Dilain pihak, regulator juga harus mengawasi dengan konsisten ketaatan terhadap peraturan pemerintah tentang keamanan dan keselamatan penerbangan dan segenap peraturan penerbangan lainnya. Pemeriksaan harus dilakukan secara konsisten, terpadu, dan menyeluruh. Hal ini, meskipun membutuhkan suatu upaya yang besar namun mengingat pemeriksaan bersinggungan dengan faktor keselamatan maka menjadi suatu hal yang mutlak.

Seperti Undang-Undang Penerbangan, Peraturan Pemerintah tentang Keamanan dan Keselamatan Penerbangan menegaskan kembali bahwa pemerintah memiliki kewajiban untuk melakukan pembinaan terhadap keamanan dan keselamatan penerbangan melalui Menteri Perhubungan. Kegiatan pembinaan meliputi hal-hal sebagai berikut :

1. Semua tentang operasi pesawat udara

2. Segala pengamanan perbangan umum/sipil

3. Harus terdapat standar kelayakan udaraPelayanan 
4. Terdapat pengoprasian dan navigasi penerbangan StaRancang Bangun Pesawat Udara, Pembuatan, dan Perawatan yang terdiri dari :

a. Terdapatnya baling-baling pesawat

b. Terdapatnya mesin pesawat udara

c. Serta bagian dan komponen yang lain

Terkait dengan tragedi kecelakaan yang menimpa pesawat lion air JT 610 telah menyebabkan kesedihan yang dalam untuk keluarga korban yang ditinggalkan karena banyak sekali yang menjadi korban dalam jatuhnya pesawat tersebut jatuhnya pesawat Lion Air JT 610 beberapa waktu tentu menyisakan duka. Pada asuransi terdapat pihak-pihak, pihak penanggung yaitu perusahaan asuransi dan pihaktertanggung. Adanya duapihak tersebut, berarti perjanjian asuransi termasuk perjanjian timbal balik.

Berdasarkan Pasal 2 huruf a Peraturan Pelaksanaan Menteri Perhubungan Nomor 77 Tahun 2011 tentang Tanggung Jawab Pengangkut Angkutan Udara yang menyatakan bahwa "Pengangkutyang mengoperasikanpesawatudarawajib bertanggungjawabatas kerugianterhadap: (a) penumpangyang meninggaldunia, cacat tetap atau luka-luka dan Pasal 3 huruf a Peraturan Pelaksanaan Menteri Perhubungan Nomor 77 Tahun 2011 Tentang Tanggung Jawab Pengangkut Angkutan Udara yang menyatakan bahwa "semua penumpang yang diangkut oleh pesawat udara yang meninggal dunia karena kecelaakaan maupun kejadian yang ada hubungannya dengan pesawaat mauapun pengangkutan udara akan diberikann ganti kerugian sebesar Rp 1,25 miliar.

Berdasarkan hal tersebut, Penulis berpendapat bahwa kasus Lion Air JT 610, penerbangan tersebut merupakan penerbangan domestik mengingat rutenya menghubungkan dua titik dalam suatu negara. Maka hukum nasional hidup, bukan konvensi internasional, baik Konvensi Warsawa 1929 maupun Konvensi Montreal 1999. Peraturan Menteri Perhubungan Nomor 77 Tahun 2011 adalah yang menjadi acuan pemberian kompensasi bagi keluarga korban. Seandainya penumpang meninggal akibat kecelakaan, maka Rp 1,25 miliar 
Abimanyu Faiz Prajogo \& H. K. Martono TANGGUNG JAWAB PENGANGKUT TERHADAP PENUMPANG YANG TIDAK TERDAFTAR DALAM MANIFES (STUDI KASUS JATUHNYA PESAWAT LION AIR JT 610 DI KARAWANG)

Volume 2 Nomor 2, Desember 2019

E-ISSN : 2655-7347

tersedia bagi setiap ahli waris penumpang. Jumlah yang sama juga berlaku jika penumpang selamat mengalami cacat tetap akibat kecelakaan. Angka itu pas, tidak kurang atau lebih, hadir guna memastikan keluarga yang ditinggalkan dapat tetap hidup layak. Besaran tersebut tidak mengada-ada, tepatnya harus dilihat sebagai jaring pengaman bagi keluarga yang kehilangan tulang punggungnya.

Ini artinya bahwa seluruh ganti rugi harus mempunyai ddasar yang kuat berupa Undang-Undang dan wajib diberikan kepada penumpang yang dibayarkan dan menjadi kewajiban perusahaan pengangkut penerbangan melalui peerusahan asuransi konsorsium yang telah ditunjuk. Semua korban meninggal yang disebabkan oleh kecelakaan maupun kejadian yang terjadi diudara tidak hanya mendapatkan ganti rugi dari perusahaan pengangkut tetapi juga mendapatkan ganti kerugian dari pihak Jasa Raharja, karena kecelakaan yang terjadi adalah kecelaakaan transportasi. Besaran ganti kerugian untuk korban meninggal adalah sebesar 50 juta rupiah.

Didalam peraturan menteri perhubungan nomor 77 tahun 2011 tentang tanggung jawab pengangkut udara keluarga korban kecelakan berhak melakukan klaim asuransi. Semua sudah diatur didalam peraturan tersebut. Tetapi ada syarat-syarat yang harus dilakukan oleh keluarga korban sesuai dengan peraturan yang berlaku, seperti tiket, bukti bagasi yang tercatat dalam penerbangan dan bukti lain yang mendukung untuk dapat dipertanggung jawabkan. Dan juga harus dilengkapi dengan surat keterangan yang hanya bias dikeluarkan oleh pihak berwenang tentang bukti yang terjadi baik kerugian raga dan jiwa dalam bentuk akta kematian.

Di dalam Negara Indonesia terdapat 2 macam hokum yang berlaku di Indonesia yaitu penerbangan luar negeri dan penerbangan dalam negeri. Untuk penerbangan luar negeri terdapat 11 konvesi yang terkait dengan penerbangan atau angkutan udara yang telah diratifikasi di Indonesia yaitu Konvensi Tokyo, Konvensi Warsawa 1929, Konvensi Den Haag dan lain-lainnya. Sedangkan 
untuk penerbangan dalam negeri, Indonesia memberlakukan Undang-Undang No 33 Tahun 1964 tentang Asuransi Kecelakaan Penumpang.

Saat dikeluarkannya manifest penumpang dan kru pesawat Lion Air JT 610 terdapat satu penumpang yang tak terdaftar dalam manifest penumpang yang dikeluarkan oleh Lion air yang bernama Arif Yustian yang berasal dari Bogor, Jawa Barat. Orang tua korban dari penumpang tersebut mengatakan bahwa anaknya yang bernaama Arif Yustian menjadi penumpang karena menggantikan penumpang yang bernama Krisma Wijaya yaitu rekan kerja korban yang berasal dari PT Sky Pacific Indonesia yang ditugaskan oleh kantor menuju Pangkal Pinang.

Jasa Raharja hanya akan mengklaim memlalui bukti yaitu beerupa tiket. Jasa Raharja hanya akan memberikan santunan kepada penumpang yang terdaftar dan sah. Jasa raharja tidak sendiri dalam memberikan santunan kareana jasa raharja juga bekerja sama dengan maskapai terkait yaitu Lion Air. Didalam Peraturan Menteri Perhubungan Nomor 77 tahun 2011 tentang Tanggung Jawab Pengangkut Angkutan Udara, Pasal 1 ayat (7) menyebutkan bahwa penumpang memiliki hak ganti kerugian memlalui alat bukti berupa tiket yang sah.

Salah satu bukti kuat terdapatnya perjanjian dalam angkutan udara ata diangkut dengan pesawat udara tertera didalam beleid tiket. Yanag tertera dalam beleid tiket adalah proses elektronik yang dilalui, laalu berupa dokumen yang telaah dicetak, bentuk-bentuk yang lainnya. Karena hal ini yang dijaga ketat dengan regulasi regulasi pada melakukan boarding dan pihak pengganti dalam hal ini adalah jasa raharja belum dapat memberi kepastian bahwa apakah terjamin atau tidaknya.

Menurut Penulis, yang menjadi dasar didalam Jasa Raharja untuk mengeluarkan/memberikan klaim maupunn santunan kepada penumpang adalah data yang pasti. Dimana sekarang adalah baru pertama kalinya terdapat kasus tidak terdaftar didalam manifestasi penumpang. Sebelumnya Jasa Raharja belumpernah mengasihkan santunan ataupun klaim kepada penumpang yang menggantikan dan tidak terdaftar. Karena sepanjang pengalaman Jasa Raharja 
Abimanyu Faiz Prajogo \& H. K. Martono TANGGUNG JAWAB PENGANGKUT TERHADAP PENUMPANG YANG TIDAK TERDAFTAR DALAM MANIFES (STUDI KASUS JATUHNYA PESAWAT LION AIR JT 610 DI KARAWANG)

Volume 2 Nomor 2, Desember 2019 E-ISSN : 2655-7347

fisik maupun nama selalu tidak pernah beda dengan data indetitas penumpamg. Ganti kerugian didalam jaminan mempunyai dua jenis yaitu, jika mengacu kepada peraturan menteri perhubungan 77 tahun 2011Di mana ada dua jenis jaminan ganti rugi yang tersedia. Pertama, berdasarkan Undang-Undang Nomor 33 Tahun 1964 tentang Dana Pertanggungan Wajib Kecelakaan Penumpang yang dibayarkan oleh Jasa Raharja. Kedua berdasarkan Permenhub 77/2011 santunan sebesar Rp 1,25 miliar yang ditanggung oleh pihak maskapai.

\section{PENUTUP}

\section{A. Kesimpulan}

Setelah penulis menganalisis data yang diperoleh dari Bab III dan menuliskan hasil analisisnya ke dalam Bab IV, penulis dapat menarik kesimpulan bahwa kasus ini bermula karena terjadinya kecelakaan pesawat Lion Air dengan kode penerbangan JT 610 rute Jakarta menuju Pangkal Pinang pada tanggal 29 Oktober 2018. Pesawat tersebut jatuh di perairan Karawang yang membawa 178 penumpang dewasa, 1 penumpang anak-anak, 2 bayi, dan 7 awak kabin. Di dalam pesawat tersebut ada penumpang yang namanya tidak ada dalam tiket atau tidak terdaftar. PT SKY Pasific Indonesia menugaskan Krisma wijaya, Darwin Harianto dan Rohmanir Pandi Sagala ke Pangkal Pinang. Mereka bertiga ditugaskan ke Pangkal Pinang menggunakan Pesawat Lion Air yang sudah di pesan. Tiga hari sebelum keberangkatan Krisma Wijaya menginfokan bahwa ia tidak bisa pergi tugas ke Pangkal Pinang. Kemudian ketidakhadiran Krisma Wijaya digantikan oleh Arif Yustian. Pada saat mereka di tengah perjalanan menaiki pesawat udara Lion Air JT-610 rute Jakarta menuju Pangkal Pinang, pesawat terbang yang mereka tumpangi mengalami kecelakaan dan terjatuh di perairan Karawang. Pada saat pengecekan data manifes para korban kecelakaan pesawat tersebut, ternyata tidak ada terdaftar nama penumpang atas nama Arif Yustian, yang tertera dan terdaftar melainkan Krisma Wijaya. Dalam kasus-kasus pelanggaran hak 
konsumen, diperlukan kehati-hatian dalam menganalisis siapa yang harus bertanggung jawab dan seberapa tanggung jawab dapat dibebankan kepada pihak-pihak terkait. Ada faktor kelalaian di dalam perusahaan tersebut, tetapi setelah diproses melalui jalur hukum, pihak perusahaan penerbangan mengakui kesalahan tersebut dikarenakan belum ter-update.

B. Saran

Dalam penjelasan Undang-Undang Penerbangan, dikatakan bahwa Indonesia (dalam hal ini adalah Pemerintah) memiliki kewajiban untuk menyelaraskan pengaturan sistem penerbangannya dengan ketentuanketentuan yang terkandung di dalam Konvensi Chicago 1944. Dengan adanya ketentuan ini, terdapat satu kejelasan bahwa pengaturan sistem penerbangan di indonesia diharuskan untuk mengacu pada ketenttuan internasional. Selain itu, penataan terhadap ketentuan ICAO oleh Indonesia merupakan suatu konsekuensi logis dari keikutsertaan Indonesia dalam Konvensi Chicago 1944 yang melahirkan ICAO. keselamatan penerbangan merupakan suatu kondisi yang hanya dapat terwujud dengan penataan terhadap prosedur operasi dan persyaratan teknis terhadap sarana prasarana penerbangan. Dikarenakan penekanan terhadap keselamatan penerbangan terpaku pada kata penataan, maka segenap ketentuan dalam peraturan pemerintah tentang Keamanan dan Keselamatan Penerbangan ditujukan kepada pihak operator dan regulator.

\section{DAFTAR PUSTAKA}

\section{A. Buku}

Carriers Law Legislation Indonesia, Seminar Hukum Pengangkutan Udara. (Jakarta, Penerbit Binacipta, 1980).

Fitriyanti, Fadia dan Sentot Yulianugroho. Hukum Perniagaan Internasional. (Yogyakarta: Lab Hukum Universitas Muhammadiyah Yogyakarta, 2007). 
Abimanyu Faiz Prajogo \& H. K. Martono TANGGUNG JAWAB PENGANGKUT TERHADAP PENUMPANG YANG TIDAK TERDAFTAR DALAM MANIFES (STUDI KASUS JATUHNYA PESAWAT LION AIR JT 610 DI KARAWANG)

Volume 2 Nomor 2, Desember 2019

E-ISSN : 2655-7347

Kamaluddin, Rustian. Ekonomi Transportasi: Karekteristik, Teori dan Kebijakan. (Jakarta: Ghalia Indonesia,2003).

Martono, H.K \& Agus Pramono. Hukum Udara Perdata Nasional dan Internasional. (Jakarta: Raja Grafindo Persada, 2013).

Marzuki, Peter Mahmud. Metode Penelitian Hukum. Cetakan ke-4.( Jakarta: Kencana, 2008).

\section{B. Peraturan Perundang-Undangan}

Indonesia. Undang-Undang Nomor 1 Tahun 2009 tentang Penerbangan, (Lembaran Negara Republik Indonesia Tahun 2009 No.1, Tambahan Lembaran Negara Republik Indonesia 4956). 


\section{Jurnal Huknm Adigamâ}

Volume 2 Nomor 2, Desember 2019

E-ISSN : 2655-7347
Abimanyu Faiz Prajogo \& H. K. Martono TANGGUNG JAWAB PENGANGKUT TERHADAP PENUMPANG YANG TIDAK TERDAFTAR DALAM MANIFES (STUDI KASUS JATUHNYA PESAWAT LION AIR JT 610 DI KARAWANG)

. Undang-Undang Nomor 40 Tahun 2014 tentang Perasuransi (Lembaran Negara Republik Indonesia Tahun 2014 Nomor 337, Tambahan Lembaran Negara Republik Indonesia Nomor 5618). . Peraturan Menteri Perhubungan No.77 Tahun 2011 tentang Tanggungjawab Pengangkut Angkutan Udara. . Peraturan Pemerintah Nomor 40 Tahun 1995 tentang Angkutan Udara (Lembaran Negara Republik Indonesia Tahun 1995 Nomor 68, Tambahan Lembaran Negara Republik Indonesia Nomor 3610).

\section{Karya Ilmiah / Jurnal}

Julianto, Abidin A. Kurnia Ecla. Tanggung Jawab Maskapai Penerbangan Terhadap Penumpang dan Bagasi Kabin dalam Kecelakaan Pengangkutan Udara di Indonesia. (Skripsi, Universitas Muhammadiyah Yogyakarta, 2015.

Wiradipradja, E. Saefullah. Tanggung Jawab Perusahaan Penerbangan Terhadap Penumpang Menurut Hukum Udara Indonesia. Jurnal Hukum Bisnis Vol. 25, 2006.

Wagiman. Refleksi dan Implemantasi Hukum Udara: Studi Kasus Pesawat Adam Air. Jurnal Hukum Bisnis Vol. 25, 2006. 